\title{
Por uma Terceira Idade Saudável: Programa Melhor Idade
}

\section{Ernane Ervino Pfüller}

Engenheiro Agrônomo e Educador Físico. Próreitor de Extensão, Universidade Estadual do Rio Grande do Sul.

E-mail: ernane-pfuller@uergs.edu.br

Nos últimos anos, diversos estudos têm colocado em discussão o conceito de saúde, distanciando-se do entendimento como ausência de doenças ou enfermidades e passando-se a incorporar um significado mais abrangente que incluiu os múltiplos aspectos que a envolve. Ao mesmo tempo, os cuidados com a promoção de saúde passaram a se intensificar nas sociedades modernas, que tem envidado esforços para mudanças de comportamento que atenuem processos degenerativos, garantam uma maior expectativa de vida, maior produtividade no trabalho e menores custos com tratamentos. Estas mudanças perpassam ações preventivas com adoção de uma alimentação mais saudável, maior educação e informação e demais atitudes que melhorem o equilíbrio físico, mental, espiritual e social, permitindo ao ser humano estar bem consigo mesmo.

Mudanças de hábitos que atuam de forma preventiva contribuindo para um envelhecimento saudável como redução de obesidade, do uso de fumo, de álcool, do consumo de açúcar, do estresse, etc, favorecem para melhorar a qualidade de vida a medida que os anos avançam. Contudo, o estilo de vida moderno, principalmente nas grandes cidades, contribui para o sedentarismo e obesidade o que gera, por conseguinte, uma população idosa com mais pro- 
blemas. Além disso, a prática regular de alguma atividade física, é de fundamental importância para uma vida saudável, não importando o tipo de atividade, desde que o corpo se movimente regularmente.

Neste sentido, conforme aponta Andrades-Filho (2016), existem muitas dúvidas sobre o quanto estamos preparados científica e tecnologicamente para contarmos com uma população que tende a ser cada vez mais idosa. A Constituição Federal, promulgada em 1988, deixou clara a preocupação e a necessidade de se dar mais atenção ao idoso. Além disso, o Estatuto do Idoso assegura a essas pessoas o direito a educação com adequação dos currículos, metodologias e material didático aos programas educacionais a ele destinados.

As instituições de ensino superior (IES) do Brasil já têm se voltado para essa questão, pois cerca de 200 faculdades e universidades em todo o país já possuem cursos voltados para a terceira idade. Existe uma demanda por cursos voltados a esse público mais maduro, pois as pessoas aposentadas têm tempo livre e, algumas vezes, dinheiro disponível para investirem na formação e capacitação.

Surge, desta forma, a necessidade emergente de se criar políticas sociais que preparem a sociedade para a realidade na qual o percentual da população da $3 a$ Idade é cada vez maior. O público idoso tem pressa de aprender e possui em sua história as experiências da vida. Estão ocupando, cada vez mais, os espaços nas salas de aula. Esta maior presença do idoso no ambiente escolar traz diversos benefícios sociais, uma vez que, diversos estudos têm apontado inclusive o retardo do aparecimento de doenças degenerativas como o Alzheimer, e outras doenças atribuídas à atrofia por desuso e ao declínio da capacidade intelectual, que já pode iniciar 
entre 30 e 35 anos de idade. Assim, diversos trabalhos têm gerado novas descobertas que remetem para a necessidade de ações preventivas visando ter-se uma população idosa com melhor qualidade de vida.

Visando contribuir com esta realidade, a Uergs, por meio de uma ação inovadora e transformadora dedica-se a este "novo" público por meio do Programa de Extensão "Uergs na Melhor Idade", que inclui o público da 3a Idade nas aulas de graduação. Os docentes da Universidade são convidados a disponibilizar vagas ociosas dos seus cursos (componentes curriculares) para serem ocupados por pessoas a partir dos 30 anos, sendo que a prioridade para ocupar as vagas é a maior idade. A idade mínima já contempla a nova visão sobre o envelhecimento humano, preconizando práticas preventivas para o enfrentamento da passagem do tempo até a fase da 3a idade plena. O Programa então contempla três pontos importantes da função social da instituição: 1) oferecer ao público externo a oportunidade de se integrar, aprender e contribuir para o andamento das disciplinas; 2) oferecer a ocupação das vagas ociosas, aproveitando ao máximo os espaços disponíveis para atender a população e 3) contribuir para o desenvolvimento pleno e preparação das pessoas para a Melhor Idade ao oferecer as oportunidades de ocupar os bancos escolares da instituição.

$\mathrm{Na}$ sua segunda edição o Programa tem apoio externo de diversos órgão e, atualmente, existe um convênio com a Fundação Maçônica Educacional (FME) para integrar a comunidade maçônica (composta em sua maioria por pessoas com mais de 45 anos) nas ações da Uergs. Esperamos em breve contar com apoio de mais instituições, como forma de mostrar a importância de inclusão em todas as instâncias da sociedade. Até o momento a maior adesão é do público feminino, que ocupa mais de dois terços das vagas, e o 
interesse das mulheres começa mais cedo, sendo em média as mulheres mais jovens que os homens que procuram o Programa.

A Universidade aposta nesta ação por acreditar que, bem mais do que a formação dos participantes, garante, por meio da socialização de pessoas maduras e ativas com os acadêmicos meIhorias nas relações intergeracionais, principalmente diminuindo preconceitos. Constitui-se assim um espaço rico de trocas de saberes entre estes adultos/ idosos e os jovens que ainda descobrem 0 mundo, melhorando a qualificação profissional e social de todos os envolvidos por meio da troca de experiências múltiplas.

\section{Referências}

ANDRADES-FILHO, Clódis de Oliveira. A Ciência serve, antes de tudo, para garantir a qualidade de vida. Revista Eletrônica Científica da UERGS, [S.I.], v. 2, n. 3, p. 205-206, fev. 2017. Disponível em: <http://revista.uergs.edu.br/index.php/revuergs/article/view/914>. Acesso em: 26 mar. 2017. doi: http://dx.doi.org/10.21674/24480479.23.205-206. 